\title{
KOMBINASI ENZIM POLIGALAKTURONASE DAN ENZIM PEKTINESTERASE PADA KLARIFIKASI SARI BUAH NAGA SUPER MERAH (Hylocereus Costaricensis) DALAM PEMBUATAN SIRUP
}

\author{
COMBINATION OF POLYGALACTURONASE AND PECTINESTERASE ENZYME IN \\ SUPER RED DRAGON FRUIT (Hylocereus costaricensis) JUICE CLARIFICATIONS FOR \\ SYRUP PRODUCTION
}

\author{
Esti Widowati, Ardhea Mustika Sari, Rokhimah Sudarmi Ningsih \\ Program Studi Ilmu Teknologi Pangan, Universitas Sebelas Maret \\ Jl. Ir. Sutami 36A Kentingan Jebres Surakarta 57126 \\ Email : esti_widowati@yahoo.com, estiwidowati@staff.uns.ac.id
}

Diserahkan [5 Desember 2019]; Diterima [30 Januari 2020]; Dipublikasi [19 Februari 2020]

\begin{abstract}
The aim of this research was to investigate the effect of polygalacturonase enzyme (PG) from Bacillus licheniformis strain GD2a AR2 0.09\%, 0.1\%, and 0.11\% concentration combine with pectinesterase enzyme (PE) from Bacillus licheniformis strain GD2a KK2 0.5\%, 1\%, and 1.5\% concentration on the super red dragon fruit juice clarification in syrup production based in $\mathrm{pH}$, total soluble solids, transmittance, and viscosity. Polygalacturonase enzyme hydrolyzed the $\alpha$-1,4-D-glycosidic form galacturonic acid while the pectinesterase enzyme broke the metoxyl group of pectin form pectat acid. Both PG and PE enzymes worked together to hydrolyze pectin. Pectinesterase catalyzed pectin become pectat acid as the substrate for polygalacturonase. In the lower acid degree, polygalcturonase and pectinesterase enzyme combination cause the viscosity and total soluble solid decreased. Degradation of pectin cause the transmittance of super red dragon fruit syrup increased. The result of this research were obtained a partially purified polygalacturonase enzyme with enzyme activity $0.31 \mathrm{U} / \mathrm{ml}$ while the pectinesterase enzyme activity was $1.167 \mathrm{U} / \mathrm{ml}$. Samples with the addition $0.11 \%$ concentration of polygalacturonase enzyme and $0.5 \%$ concentration of pectinesterase enzyme with $\mathrm{pH}$ value of 4.303 , total soluble solid value of $38.133^{\circ}$ Brix, transmittance value of $74.5 \%$, and viscocity value of $0.128 \mathrm{cP}$ was selected sample.
\end{abstract}

Keywords: clarification, enzyme, fruit syrup, pectin, pectinesterase, polygalacturonase, super red dragon fruit

\section{ABSTRAK}

Tujuan dari penelitian ini adalah untuk mengetahui pengaruh penggunaan enzim poligalakturonase (PG) bakteri Bacillus licheniformis strain GD2a AR2 pada konsentrasi 0,09\%, 0,1\%, dan 0,11\% dengn enzim pektinesterase (PE) Bacillus licheniformis strain GD2a KK2 pada konsentrasi 0,5\%, 1\%, dan 1,5\% pada klarifikasi sari buah naga super merah dalam pembuatan sirup terhadap parameter $\mathrm{pH}$, total padatan terlarut, transmitansi, dan viskositas. Enzim poligalakturonase menghidrolisis ikatan $\alpha-1,4-$ D-glikosidik membentuk asam galakturonat. Enzim pektinesterase bekerja pada ikatan ester senyawa pektin sehingga dihasilkan asam pektat. Enzim poligalakturonase dan enzim pektinesterase bekerja secara sinergis. Enzim pektinesterase mengkatalis pektin menjadi asam pektat yang merupakan substrat untuk enzim poligalakturonase. Pada $\mathrm{pH}$ yang rendah, penggunaan enzim poligalakturonase dan enzim pektinesterase dapat menurunkan viskositas dan nilai total padatan terlarut sirup buah naga super merah. Degradasi pektin meningkatkan transimtansi sirup buah naga super merah. Hasil penelitian ini diperoleh enzim poligalakturonase murni parsial dengan aktivitas enzim 0,31 $\mathrm{U} / \mathrm{ml}$ dan enzim pektinesterase murni parsial dengan aktivitas enzim 1,167 U/ml. Sampel dengan penambahan enzim poligalakturonase $0,11 \%$ dan enzim pektinesterase $0,5 \%$ dengan nilai $\mathrm{pH} 4,303$, nilai total padatan terlarut $38,133^{\circ}$ Brix, nilai transmitansi $74,5 \% \mathrm{~T}$, nilai viskositas $0,128 \mathrm{cP}$ merupakan sampel terpilih.

Kata kunci: buah naga super merah, enzim, klarifikasi, pektin, pektinesterase, poligalakturonase, sirup buah

\section{PENDAHULUAN}

Buah naga super merah (Hylocereus costaricenss) memiliki kandungan nutrisi dan mineral seperti vitamin B1, vitamin B2, vitamin B3 dan vitamin $\mathrm{C}$, protein, lemak, karbohidrat, serat kasar, flavonoid, tiamin, niasin, piridoksin, kobalamin, glukosa, fenolik, betasianin, polifenol, karoten, fosfor, besi, dan fitoalbumin (Jaafar et al., 2009). Buah naga segar tidak dapat disimpan lama, karena memiliki kadar air yang tinggi yaitu 90\% dan umur simpan 7-10 hari pada suhu $14^{0} \mathrm{C}$ (Farikha, 2013). Salah satu upaya untuk mempertahankan mutu buah naga merah adalah dengan mengolahnya menjadi sirup. 
Berdasarkan SNI 3544 (2013) sirup merupakan produk minuman yang dibuat dari campuran air dan gula dengan kadar larutan gula minimal $65 \%$ dengan atau tanpa bahan pangan lain dan atau bahan tambahan pangan yang diijinkan sesuai ketentuan yang berlaku. CV. Wana Bekti Handayani telah memproduksi sirup buah naga super merah dengan cara konvensional. Sirup yang diproduksi oleh CV. Wana Bekti Handayani dalam kurun waktu satu bulan menunjukkan adanya endapan di bagian bawah botol kemasan. Endapan tersebut dapat berupa polisakarida seperti pektin dan hemiselulosa yang menyebabkan kekeruhan pada sari buah naga super merah pada umumnya.

Senyawa pektin merupakan senyawa yang terdapat di seluruh jaringan tanaman, terutama sebagai komponen lamella tengah yang berperan sebagai perekat antar dinding sel; bercampur dengan selulosa dan hemiselulosa. Kekeruhan dalam sirup buah dapat diturunkan dengan degradasi pektin.

Menurut Beg et al., (2001) penjernihan sirup dapat dilakukan dengan cara enzimatis yaitu dengan penambahan enzim xilanase, selulase dan pektinase. Degradasi pektin oleh aktivitas enzim dapat menurunkan viskositas sari buah dan meningkatkan rendemen (Plocharski et al., 1998 dalam Sharma et al., 2014). Enzim poligalakturonase bekerja memutus ikatan $\alpha-1,4$ glikosidik pada rantai asam poligalakturonat secara hidrolisis sehingga dapat menurunkan viskositas sari buah (Ortega et al., 2004; Pedrolli et al., 2009). Enzim pektinesterase bekerja dengan memutuskan ikatan gugus metoksi dari pektin menghasilkan asam pektat dan metanol (Sharma et al., 2014).

Konsentrasi enzim poligalakturonase yang digunakan yaitu $0,09 \%, 0,1 \%, 0,11 \%$. Konsentrasi enzim pektinesterase yang digunakan yaitu $0,5 \%, 1 \%, 1,5 \%$. Penggunaan kombinasi kedua enzim tersebut diharapkan dapat mengklarifikasi sirup buah naga super merah secara optimal

\section{METODE PENELITIAN}

\section{Bahan}

Buah naga super merah (Hylocereus costaricensis) diperoleh dari Keboen Naga
CV Naga Jaya Makmur, Malang, Jawa Timur. Enzim yang digunakan untuk klarifikasi sirup buah naga super merah ialah enzim poligalakturonase didapatkan dari bakteri Bacillus licheniformis strain GD2a AR2 dan enzim pektinesterase bakteri Bacillus licheniformis strain GD2a KK2. Bahan-bahan analisis antara lain aquadest, yeast extract (OXOID), disodium hidrogen fosfat $\left(\mathrm{Na}_{2} \mathrm{HPO}_{4}\right)$, potasium dihidrogen fosfat $\left(\mathrm{KH}_{2} \mathrm{PO}_{4}\right)$, natrium dihidrogen fosfat $\left(\mathrm{NaH}_{2} \mathrm{PO}_{4}\right)$, magnesium sulfat $\left(\mathrm{MgSO}_{4} \cdot 7 \mathrm{H}_{2} \mathrm{O}\right)$, kalium klorida $(\mathrm{KCl})$, amonium sulfat $\left(\left(\mathrm{NH}_{4}\right)_{2} \mathrm{SO}_{4}\right)$, bacteriological agar, asam asetat $\left(\mathrm{CH}_{3} \mathrm{COOH}\right)$, natrium asetat $\left(\mathrm{CH}_{3} \mathrm{COONa}\right)$, barium klorida $\left(\mathrm{BaCl}_{2}\right)$ dengan semua bahan bermerek MERCK. Aquades, alkohol $90 \%$, buffer asetat 0,05 M ( $\mathrm{pH} 5,2)$, buffer fosfat $0,05 \mathrm{M}(\mathrm{pH} \mathrm{7)}$ dan pektin citrus.

\section{Proses Persiapan Isolat}

Sebanyak 1 ose kultur koleksi digoreskan pada media pektin agar miring untuk kemudian diinkubasi pada suhu $55^{\circ} \mathrm{C}$ selama 24 jam. Persiapan isolat pada media cair dilakukan dengan menggoreskan 1 ose dari subkultur ke dalam $10 \mathrm{ml}$ media pektin cair. Inkubasi dilakukan pada suhu $55{ }^{0} \mathrm{C}$ selama 24 jam (Widowati, et al., 2017). Perhitungan sel dilakukan pada saat sebelum dan setelah inkubasi.

\section{Produksi Enzim}

Dilakukan dengan cara pembuatan stok inokulum. Setelah melalui proses inkubasi, $10 \mathrm{ml}$ inokulum tersebut ditambahkan $90 \mathrm{ml}$ media pektin cair kemudian diinkubasi pada shaker incubator dengan kecepatan agitasi $144 \mathrm{rpm}$ pada suhu $55^{\circ} \mathrm{C}$. Waktu optimal produksi bakteri Bacillus licheniformis strain GD2a AR2 adalah 10 jam (Widowati, et al, 2017). sedangkan untuk bakteri Bacillus licheniformis strain GD2a KK2 adalah 7 jam (Utami dkk., 2015).

\section{Isolasi dan Ekstraksi Enzim}

Sentrifugasi suspensi sel dari hasil inkubasi dalam media pektin cair dengan kecepatan $6.000 \mathrm{rpm}$, suhu $4^{\circ} \mathrm{C}$ selama 15 menit. 


\section{Pemurnian Parsial Enzim dengan Presipitasi Amonium Sulfat dan Dialisis}

Supernatan enzim PG dipresipitasi dengan fraksinasi amonium sulfat $50 \%$ dengan aktivitas tertinggi enzim sebesar 0,09 $\mathrm{U} / \mathrm{ml}$ (Widowati, et al, 2017). Supernatan enzim PE dipresipitasi dengan fraksinasi amonium sulfat $60 \%$ dengan aktivitas tertinggi enzim sebesar 0,093 U/ml (Utami dkk., 2015). Untuk enzim poligalakturonase, nilai kejenuhan $50 \%$ adalah 313 g per liter dengan supernatan $850 \mathrm{ml}$, sehingga amonium sulfat yang ditambahkan sebanyak $=0,8501 \times 313 \mathrm{~g} / \mathrm{l}=266,05 \mathrm{~g}$. Untuk enzim pektinesterase, nilai kejenuhan $60 \%$ adalah $390 \mathrm{~g}$ per liter dengan supernatan $850 \mathrm{ml}$, sehingga amonium sulfat yang ditambahkan sebanyak $=0,8501 \times 390 \mathrm{~g} / \mathrm{l}=331,5 \mathrm{~g}$.

Supernatan dibiarkan selama 24 jam pada suhu $4^{0} \mathrm{C}$. Setelah presipitasi, supernatan disentrifugasi $12.000 \mathrm{rpm}$ pada suhu $4{ }^{0} \mathrm{C}$ selama 10 menit. Disuspensikan dengan buffer asam asetat $0,05 \mathrm{M} \mathrm{pH} 5,2$ (enzim PG) dan buffer asam fosfat 0,05 M pH 7 (enzim PE) perbandingan 1:1.

Kantong dialisis/selofan direndam dalam aquades selama 24 jam. Salah satu ujung kantong dialisis diikat erat dan endapan yang telah didapatkan dari proses presipitasi dimasukkan kedalam ujung kantong dialisis. Ujung lain dari kantong dialisis kemudian diikat untuk mencegah kebocoran. Setelah itu, kantong dialisis direndam dalam gelas kimia yang berisi buffer (sesuai jenis enzim) selama 24 jam pada suhu $4^{0} \mathrm{C}$ sambil diaduk dengan magnetic stirrer. Pergantian buffer pada proses dialisis, dilakukan sebanyak 3 kali setiap 8 jam sekali selama 24 jam dialisis serta dicek kandungan amonium sulfat dalam larutan dengan meneteskan $\mathrm{BaCl}_{2} 1 \%$. Amonium sulfat akan bereaksi dengan $\mathrm{BaCl}_{2}$ membentuk endapan putih $\mathrm{BaSO}_{4}$. Dialisis dihentikan ketika penambahan $\mathrm{BaCl}_{2}$ tidak membentuk endapan putih lagi.

\section{Uji Aktivitas Enzim}

Aktivitas enzim PG ditentukan dengan mengukur gula reduksi yang dibebaskan dari pektin dengan menggunakan metode DNS. Sebanyak $0,1 \mathrm{ml}$ enzim ditambah dengan 0,9 $\mathrm{ml}$ media pereaksi terdiri dari $(0,7 \% \mathrm{w} / \mathrm{v})$ pektin sitrus dan $0,025 \mathrm{M}$ buffer natrium asetat pH 4,8 (Ordonez et al., 1998). Enzim tersebut kemudian diinkubasi pada suhu 55 ${ }^{0} \mathrm{C}$ selama 30 menit. Aktivitas enzim diukur dengan menambahkan $1 \mathrm{ml}$ reagen DNS, selanjutnya dipanaskan pada suhu $90^{\circ} \mathrm{C}$ selama 10 menit. Larutan kemudian didinginkan dan diberi K-Na-Tatrat $40 \%$ sebanyak $0,5 \mathrm{ml}$, lalu divortex. Blanko yang digunakan adalah enzim yang diinaktif dengan perlakuan sesuai dengan sampel enzim. Kemudian dilakukan pengukuran absorbansi pada panjang gelombang $540 \mathrm{~nm}$. Nilai absorbansi disubstitusikan ke dalam persamaan dari kurva standar asam galakturonat. Aktivitas enzim (U/ml) didapatkan dari perhitungan:

Aktivitas poligalakturonase $(\mathrm{Unit} / \mathrm{ml})=$

$$
\frac{\mathrm{X}}{0,1 \times \mathrm{t} \times \mathrm{BM}}
$$

Keterangan :

$\mathrm{X}=$ jumlah gula tereduksi sampel

$\mathrm{T}=$ waktu inkubasi (menit)

$\mathrm{BM}=\mathrm{BM}$ asam galakturonat $(194,139 \mathrm{~g} / \mathrm{mol})$

Untuk aktivitas enzim pektinesterase dilakukan dengan metode titrasi Kertez (1995) pada suhu $30^{\circ} \mathrm{C}$ dan $\mathrm{pH}$ 7. Aktivitas enzim pektinesterase dihitung dengan rumus:

Aktivitas pektinase $(\mathrm{Unit} / \mathrm{ml})=$

$$
\frac{\left(\mathrm{V}_{\mathrm{s}}-\mathrm{V}_{\mathrm{b}}\right) \times \mathrm{N} \mathrm{NaOH} \times 1000}{\mathrm{t} \times \mathrm{V}_{\mathrm{t}}}
$$

Keterangan:

$\mathrm{Vs}=$ Volume $\mathrm{NaOH}$ untuk mentitrasi larutan reaksi $(\mathrm{ml})$

$\mathrm{Vb}=$ Volume $\mathrm{NaOH}$ untuk mentitrasi larutan blanko (ml)

$\mathrm{N} \mathrm{NaOH}=0,01 \mathrm{~N}$

$\mathrm{T}=$ Waktu inkubasi (menit)

$\mathrm{Vt}=$ Volume enzim $(0,2 \mathrm{ml})$

Sebanyak $5 \mathrm{ml}$ larutan substrat pektin (citrus pectin (SIGMA) $1 \%$ dalam $0,1 \mathrm{M}$ $\mathrm{NaCl} \mathrm{pH}$ 7) dan $0,2 \mathrm{ml}$ isolat enzim pektinesterase dimasukkan kedalam tabung reaksi dan $\mathrm{pH}$ diatur kembali pada $\mathrm{pH} 7$. Campuran diinkubasi pada suhu $30{ }^{\circ} \mathrm{C}$ dalam circulating bath (HAAKE DL 30) selama 30 menit. Setelah itu dilakukan pengukuran $\mathrm{pH}$ akhir, lalu $\mathrm{pH}$ akhir dikembalikan ke $\mathrm{pH}$ awal dengan penambahan $\mathrm{NaOH} 0,01 \mathrm{~N}$. Volume $\mathrm{NaOH} 0,01 \mathrm{~N}$ yang ditambahkan digunakan untuk penentuan aktivitas enzim. 
Larutan pektin $1 \%$ tanpa penambahan enzim dengan perlakuan yang sama digunakan sebagai Blanko.

\section{Penentuan Kombinasi Variasi Konsentrasi Enzim}

Tabel 1 Variasi Konsentrasi Enzim Poligalakturonase dan Pektinesterase

\begin{tabular}{|c|c|c|c|c|}
\hline \multirow[b]{2}{*}{ Enzim PG } & \multicolumn{4}{|c|}{ Enzim PE } \\
\hline & $\begin{array}{l}0 \% \\
\text { (B0) }\end{array}$ & $\begin{array}{c}0,5 \% \\
\text { (B1) }\end{array}$ & $\begin{array}{l}1 \% \\
\text { (B2) }\end{array}$ & $\begin{array}{c}1,5 \% \\
\text { (B3) }\end{array}$ \\
\hline $0 \%(\mathrm{~A} 0)$ & A0B0 & A0B1 & $\mathrm{A} 0 \mathrm{~B} 2$ & A0B3 \\
\hline $0,09 \%(\mathrm{~A} 1)$ & A1B0 & A1B1 & A1B2 & A1B3 \\
\hline $0,1 \%(\mathrm{~A} 2)$ & A2B0 & A2B1 & A2B2 & A2B3 \\
\hline $0,11 \%(\mathrm{~A} 3)$ & A3B0 & A3B1 & A3B2 & A3B3 \\
\hline
\end{tabular}

Pembuatan Sirup Buah Naga Super Merah

Proses pembuatan sirup buah naga super merah meliputi: sortasi buah, pencucian, pengupasan, pemotongan, penghancuran daging buah, perebusan I, perebusan II, pencampuran, pengadukan, pengisian, pasteurisasi, pendinginan, pengemasan. Volume sari buah naga super merah pada setiap sampel ialah $50 \mathrm{ml}$ dengan 16 sampel perlakuan dan 3 kali pengulangan sampel.

Sampel diinkubasi pada suhu $55^{\circ} \mathrm{C}$ selama 60 menit. Sampel yang telah diberikan perlakuan dengan enzim, kemudian dicampur dengan air rebusan gula, dan asam sitrat. Sampel dibiarkan pada suhu ruang selama 25 menit dan selanjutnya diujikan nilai $\mathrm{pH}$, total padatan terlarut (TPT), transmitansi dan viskositas.

Pengujian Klarifikasi Sirup Buah Naga Super Merah

pH

Pengukuran $\mathrm{pH}$ menggunakan $\mathrm{pH}$ meter. Batang probe $\mathrm{pH}$ meter dicelupkan kedalam larutan dan $\mathrm{pH}$ otomatis akan terlihat pada angka.

\section{Total Padatan Terlarut}

Sampel yang akan diuji TPT diteteskan pada area uji hand refractometer. Hasil dapat dilihat pada skala tanda batas pengamatan

\section{Transmitansi}

Nilai transmitansi dilihat dengan spektrofotometer dengan panjang gelombang maksimum, yaitu $535 \mathrm{~nm}$.

\section{Viskositas}

Nilai viskositas diukur menggunakan viskometer falling ball. Waktu yang diamati melalui stopwatch merupakan waktu yang diperlukan bola untuk jatuh pada jarak tertentu. Viskositas cairan dihitung dengan persamaan berikut:

$$
\mu=\frac{t\left(2 g r^{2}\left(\rho-\rho_{0}\right)\right.}{9 d}
$$

$$
\begin{array}{ll}
\text { Keterangan: } \\
\mu & =\text { viskositas dinamis }(\mathrm{mPa} . \mathrm{s}) \\
\mathrm{t} & =\text { waktu bola jatuh }(\mathrm{s}) \\
\mathrm{g} & =\text { gravitasi }\left(\mathrm{cm} / \mathrm{s}^{2}\right) \\
\mathrm{r} & =\text { jari-jari bola }(\mathrm{cm}) \\
\rho_{0} & =\text { densitas sampel }\left(\mathrm{g} / \mathrm{cm}^{3}\right) \\
\rho & =\text { densitas bola }\left(8,1 \mathrm{~g} / \mathrm{cm}^{3}\right) \\
\mathrm{d} & =\text { jarak }
\end{array}
$$

\section{HASIL DAN PEMBAHASAN}

\section{Hasil Klarifikasi Sirup Buah Naga Super Merah}

Enzim poligalakturonase (PG) dengan aktivitas enzim murni parsial sebesar 0,31 $\mathrm{U} / \mathrm{ml}$ diperoleh dari bakteri Bacillus licheniformis Strain GD2a AR2, sedangkan enzim pektinesterase (PE) dengan aktivitas enzim murni parsial sebesar $1,167 \mathrm{U} / \mathrm{ml}$ diperoleh dari bakteri pektinolitik Bacillus licheniformis Strain GD2a KK2. Sirup dengan kombinasi enzim poligalakturonase (PG) pada konsentrasi 0\%, 0,09\%, 0,1\%, dan $0,11 \%$ dan enzim pektinesterase (PE) pada konsentrasi $0 \%, 0,5 \%, 1 \%$, dan $1,5 \%$ diuji berdasarkan parameter $\mathrm{pH}$, total padatan terlarut, transmitansi, dan viskositas.

\section{pH}

Tujuan dari pengukuran nilai $\mathrm{pH}$ adalah untuk mengetahui perubahan tingkat keasaman dari sirup buah naga super merah. Hasil analisis klarifikasi sari buah naga super merah dalam pembuatan sirup terhadap parameter $\mathrm{pH}$ secara umum tidak mengalami perubahan.

Berdasarkan analisis two way anova penambahan enzim poligalakturonase pada berbagai konsentrasi tidak berpengaruh terhadap $\mathrm{pH}$. Nilai $\mathrm{pH}$ sirup buah naga super merah dengan penambahan enzim poligalakturonase berkisar antara 4,24 $\pm 0,00$ hingga 4,29 $\pm 0,02$. Perlakuan penambahan enzim pektinesterase pada klarifikasi sari 
buah naga super merah dalam pembuatan sirup tidak berpengaruh terhadap nilai $\mathrm{pH}$. Kisaran nilai $\mathrm{pH}$ dengan variasi konsentrasi enzim pektinesterase berkisar antara 4,25 \pm 0,00 hingga 4,27 $\pm 0,02$. Berdasarkan Tabel 2, interaksi antara enzim poligalakturonase dan enzim pektinesterase tidak berpengaruh terhadap nilai $\mathrm{pH}$ sirup buah naga super merah hasil klarifikasi. Interaksi tersebut mempunyai nilai korelasi yang lemah.

Nilai $\mathrm{pH}$ sirup buah naga super merah hasil penelitian berkisar antara 4,24 $\pm 0,02$ hingga 4,31 $\pm 0,08$. Pektin dalam jaringan tanaman banyak dalam bentuk protopekin yang tidak larut dalam air. Kondisi $\mathrm{pH}$ rendah akan menghidrolisis protopektin menjadi pektin yang lebih mudah larut (Hariyati, 2006). Pada kondisi asam, ikatan glikosidik gugus metil ester dari pektin cenderung terhidrolisis menghasilkan asam galakturonat (Smith dan Bryant, 1968). Asam galakturonat (D-galakturonat) merupakan asam lemah karena memiliki nilai pKa 3,51 (Kulvanen et al., 2012; Kohn dan Kovac, 1978) sehingga menyumbang sedikit asam.
Enzim poligalakturonsae dan enzim pektinesterase yang digunakan dalam penjernihan sirup buah naga super merah kinerjanya dapat dipengaruhi oleh inhibitor. Inhibitor tersebut dapat berupa ion-ion logam yang terkandung dalam buah-buahan. Kandungan magnesium (Mg) dalam daging buah naga super merah $60,4 \mathrm{mg} / \mathrm{g}$ daging buah sedangkan kandungan kalsium (Ca) adalah 134,5 mg/g daging buah (Kristanto, 2008). Konsentrasi $4 \mathrm{mM}$ ion $\mathrm{Zn}^{2+} ; \mathrm{Mg}^{2+}$ menjadi inhibitor untuk aktivitas pektinase sedangkan untuk ion $\mathrm{Ca}^{2+}$ mulai konsentrasi $6 \mathrm{mM}$ (Anggraini, 2013).

\section{Total Padatan Terlarut (TPT)}

Komponen yang terukur sebagai total padatan terlarut pada sirup buah naga super merah pada penelitian ini antara lain sukrosa, gula pereduksi, asam organik, dan protein. Hasil analisis total padatan terlarut (TPT) pada klarifikasi sari buah naga super merah dalam pembuatan sirup secara umum mengalami penurunan dibandingkan dengan kontrol.

Tabel 2 Hasil Analisis Klarifikasi Sari Buah Naga Super Merah dalam Pembuatan Sirup terhadap parameter $\mathrm{pH}$

\begin{tabular}{|c|c|c|c|c|c|}
\hline \multirow{2}{*}{$\begin{array}{c}\text { Enzim } \\
\text { PG }\end{array}$} & \multicolumn{4}{|c|}{ Enzim PE } & \multirow{2}{*}{ Rata-rata } \\
\hline & $0 \%$ & $0,5 \%$ & $1 \%$ & $1,5 \%$ & \\
\hline $0 \%$ & $4,24 \pm 0,03$ & $4,24 \pm 0,02$ & $4,23 \pm 0,02$ & $4,25 \pm 0,04$ & $4,24 \pm 0,00^{A}$ \\
\hline $0,09 \%$ & $4,25 \pm 0,05$ & $4,25 \pm 0,07$ & $4,24 \pm 0,05$ & $4,27 \pm 0,08$ & $4,25 \pm 0,01^{\mathrm{A}}$ \\
\hline $0,1 \%$ & $4,26 \pm 0,05$ & $4,25 \pm 0,05$ & $4,26 \pm 0,05$ & $4,26 \pm 0,06$ & $4,25 \pm 0,00^{\mathrm{A}}$ \\
\hline $0,11 \%$ & $4,26 \pm 0,08$ & $4,30 \pm 0,08$ & $4,31 \pm 0,08$ & $4,30 \pm 0,06$ & $4,29 \pm 0,02^{\mathrm{A}}$ \\
\hline Rerata & $4,25 \pm 0,00^{a}$ & $4,26 \pm 0,02^{a}$ & $4,26 \pm 0,03^{a}$ & $4,27 \pm 0,02^{\mathrm{a}}$ & \\
\hline
\end{tabular}

Keterangan: sig. $\mathrm{PG}=0,222 ;$ sig. $\mathrm{PE}=0,908 ;$ sig $\mathrm{PG} * \mathrm{PE}=0,998 ; \mathrm{R}$ squared $=0,168$. Notasi huruf besar dan kecil yang sama pada kolom dan baris yang sama menunjukkan tidak beda nyata pada $\alpha=0,05$

Tabel 3. Hasil Analisis Klarifikasi Sari Buah Naga Super Merah dalam Pembuatan Sirup terhadap parameter Total Padatan Terlarut $\left({ }^{\circ}\right.$ Brix $)$

\begin{tabular}{cccccc}
\hline \hline Enzim & \multicolumn{4}{c}{ Enzim PE } & \multirow{2}{*}{ Rata-rata } \\
\cline { 2 - 5 } PG & $0 \%$ & $0,5 \%$ & $1 \%$ & $1,5 \%$ & \\
\hline $0 \%$ & $40,53 \pm 0,11$ & $39,66 \pm 0,11$ & $39,13 \pm 0,23$ & $39,13 \pm 0,11$ & $39,61 \pm 0,66^{\mathrm{D}}$ \\
$0,09 \%$ & $39,26 \pm 0,11$ & $39,00 \pm 0,00$ & $39,13 \pm 0,23$ & $39,26 \pm 0,11$ & $39,16 \pm 0,12^{\mathrm{C}}$ \\
$0,1 \%$ & $39,20 \pm 0,20$ & $39,20 \pm 0,20$ & $38,73 \pm 0,11$ & $38,33 \pm 0,30$ & $38,86 \pm 0,41^{\mathrm{B}}$ \\
$0,11 \%$ & $38,30 \pm 0,20$ & $38,13 \pm 0,23$ & $38,20 \pm 0,20$ & $38,00 \pm 0,00$ & $\mathbf{3 8 . 1 5} \pm \mathbf{0 . 1 2}{ }^{\mathrm{A}}$ \\
\hline Rerata & $39,32 \pm 0,91^{\mathrm{c}}$ & $38,99 \pm 0,64^{\mathrm{b}}$ & $\mathbf{3 8 , 7 9} \pm \mathbf{0 . 4 4} \mathbf{a}^{\mathbf{3}}$ & $\mathbf{3 8 , 6 8} \pm \mathbf{0 . 6 1}$ & \\
\hline
\end{tabular}

Keterangan: sig. $\mathrm{PG}=0,000 ;$ sig. $\mathrm{PE}=0,000 ;$ sig $\mathrm{PG} * \mathrm{PE}=0,000 ; \mathrm{R}$ squared $=0,952$. Notasi huruf besar dan kecil yang sama pada kolom dan baris yang sama menunjukkan tidak beda nyata pada $\alpha=0.05$ 
Tabel 4 Hasil Analisis Klarifikasi Sari Buah Naga Super Merah dalam Pembuatan Sirup terhadap parameter Transmitansi (\% T)

\begin{tabular}{cccccc}
\hline Enzim & \multicolumn{4}{c}{ Enzim PE } & \multirow{2}{*}{ Rata-rata } \\
\cline { 2 - 5 } PG & $0 \%$ & $0,5 \%$ & $1 \%$ & $1,5 \%$ & \\
\hline $0 \%$ & $63,96 \pm 0,55$ & $72,70 \pm 1,25$ & $73,00 \pm 1,51$ & $61,30 \pm 0,90$ & $67,74 \pm 6,00^{\mathrm{A}}$ \\
$0,09 \%$ & $73,70 \pm 1,47$ & $72,70 \pm 1,08$ & $73,53 \pm 0,60$ & $60,80 \pm 1,47$ & $\mathbf{7 0 , 1 8 \pm 6 , 2 7}$ \\
$0,1 \%$ & $69,10 \pm 2,34$ & $62,26 \pm 2,74$ & $66,73 \pm 1,93$ & $72,50 \pm 1,86$ & $67,64 \pm 4,30^{\mathrm{A}}$ \\
$0,11 \%$ & $68,73 \pm 0,83$ & $74,50 \pm 1,37$ & $72,13 \pm 1,10$ & $65,13 \pm 2,75$ & $\mathbf{7 0 , 1 2 \pm 4 , 0 8}$ \\
\hline
\end{tabular}

\begin{tabular}{llll|l} 
Rerata & $68,87 \pm 3,97^{\mathrm{b}}$ & $\mathbf{7 0 , 5 4} \pm \mathbf{5 , 5 8}$ & $\mathbf{7 1 , 3 4} \pm \mathbf{3 , 1 3}$ & $64,93 \pm 5,40^{\mathrm{a}}$
\end{tabular}

Keterangan: sig. $\mathrm{PG}=0,000 ;$ sig. $\mathrm{PE}=0,000 ;$ sig $\mathrm{PG} * \mathrm{PE}=0,000 ; \mathrm{R}$ squared $=0,926$. Notasi huruf besar dan kecil yang sama pada kolom dan baris yang sama menunjukkan tidak beda nyata pada $\alpha=0,05$

Tabel 5 Hasil Analisis Klarifikasi Sari Buah Naga Super Merah dalam Pembuatan Sirup terhadap parameter Viskositas (cP)

\begin{tabular}{cccccc}
\hline Enzim & \multicolumn{4}{c}{ Enzim PE } & \multirow{2}{*}{ Rata-rata } \\
\cline { 2 - 5 } PG & $0 \%$ & $0.5 \%$ & $1 \%$ & $1.5 \%$ & \\
\hline $0 \%$ & $0,13 \pm 0,02$ & $0,13 \pm 0,01$ & $0,13 \pm 0,03$ & $0,16 \pm 0,05$ & $0,137 \pm 0,01^{\mathrm{B}}$ \\
$0,09 \%$ & $0,14 \pm 0,03$ & $0,12 \pm 0,03$ & $0,12 \pm 0,02$ & $0,10 \pm 0,01$ & $0,120 \pm 0,01^{\mathrm{AB}}$ \\
$0,1 \%$ & $0,11 \pm 0,01$ & $0,10 \pm 0,00$ & $0,10 \pm 0,00$ & $0,10 \pm 0,00$ & $\mathbf{0 , 1 0 2} \pm \mathbf{0 , 0 0}$ \\
$0,11 \%$ & $0,12 \pm 0,02$ & $0,12 \pm 0,03$ & $0,11 \pm 0,01$ & $0,11 \pm 0,01$ & $\mathbf{0 , 1 1 5} \pm \mathbf{0 , 0 0}$ \\
\hline
\end{tabular}

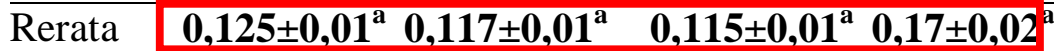

Keterangan: sig. $\mathrm{PG}=0.021$; sig. $\mathrm{PE}=0.902 ;$ sig $\mathrm{PG} * \mathrm{PE}=0.615$; $\mathrm{R}$ squared $=0.373$. Notasi huruf besar dan kecil yang sama pada kolom dan baris yang sama menunjukkan tidak beda nyata pada $\alpha=0.05$

Pada Tabel 3, nilai total padatan terlarut tertinggi terdapat pada sampel kontrol dengan nilai TPT sebesar $39,61^{\circ}$ Brix. Secara keseluruhan, nilai total padatan terlarut paling rendah ditunjukkan oleh sampel dengan penambahan enzim poligalakturonase sebesar $0,11 \%\left(38,15^{0}\right.$ Brix $)$. Kerja masingmasing enzim dan interaksi antara kedua jenis enzim berpengaruh terhadap nilai total padatan terlarut.

Hasil klarifikasi sari buah naga super merah dalam pembuatan sirup terhadap parameter total padatan terlarut dari analisis two way anova pada Tabel 3 menunjukkan adanya pengaruh penambahan enzim poligalakturonase pada beberapa konsentrasi. Nilai total padatan terlarut dari sirup buah naga super merah berkisar antara 38,15 \pm $0,12^{\circ}$ Brix hingga $39,61 \pm 0,66^{0}$ Brix. Hasil analisis two way anova klarifikasi sari buah naga super merah dalam pembuatan sirup menunjukkan adanya pengaruh enzim pektinesterase terhadap parameter total padatan terlarut. Kisaran nilai total padatan terlarut adalah $38,68 \pm 0,61^{\circ} \mathrm{Brix}$ hingga $39,32 \pm 0,91^{\circ}$ Brix. Nilai total padatan terlarut pada sirup buah naga super merah dengan kombinasi enzim poligalakturonase dan enzim pektinesterase ada pada kisaran 38,15 $\pm 0,12^{\circ}$ Brix hingga $39,61 \pm 0,66^{0}$ Brix. Berdasarkan Tabel 3, terdapat pengaruh dari interaksi antara enzim poligalakturonase dan pektinesterase terhadap hasil klarifikasi sari buah naga dalam pembuatan sirup pada parameter total padatan terlarut.

\section{Transmitansi}

Kejernihan sirup dinyatakan dengan nilai transmitansi $(\mathrm{T})$ dimana $\mathrm{T}$ merupakan perbandingan anatara intensitas cahaya yang dilewatkan oleh sampel dibandingkan dengan intensitas referensi. Semakin tinggi nilai transmitansi berarti semakin jernih larutan tersebut (Nurdjannah, 2003).

Hasil analisis transmitansi pada klarifikasi sari buah naga super merah dalam pembuatan sirup secara umum mengalami peningkatan dibandingkan dengan kontrol. Berdasarkan analisis two way anova yang ditunjukkan Tabel 4, penambahan enzim poligalakturonase berpengaruh terhadap nilai transmitansi dengan kisaran nilai antara $67,64 \pm 4,30$ hingga $70,18 \pm 6,27$. Penambahan enzim pektinesterase juga berpengaruh terhadap nilai transmitansi dengan kisaran nilai antara 64,93 $\pm 5,40$ hingga $71,34 \quad \pm \quad 3,13$. Enzim poligalakturonase dan enzim pektinesterase menunjukkan adanya interaksi yang 
mempengaruhi hasil klarifikasi sari buah naga super merah dalam pembuatan sirup. Interaksi tersebut memiliki nilai korelasi yang kuat.

Penambahan enzim poligalakturonase meningkatkan transmitansi sari buah naga super merah seiring bertambahnya konsentrasi yang digunakan karena enzim poligalakturonase mereduksi kekeruhan dengan cara mendegradasi pektin yang merupakan substansi penyebab kekeruhan sari buah. Enzim poligalakturonase yang memutus ikatan poligalakturonat menjadi asam galakturonat. Hal ini mengakibatkan luas permukaan \% transmitansi meningkat sehingga semakin banyak cahaya yang diteruskan melalui larutan sirup. Nilai \% transmitansi yang semakin tinggi menunjukkan semakin jernih larutan sirup tersebut (Ananta, 1991).

\section{Viskositas}

Viskositas atau biasanya disebut kekentalan suatu cairan menggambarkan besarnya hambatan atau resistensi cairan tersebut terhadap aliran, pengadukan atau shaker. Hasil analisis viskositas pada klarifikasi sari buah naga super merah dalam pembuatan sirup secara umum mengalami penurunan. Penambahan enzim poligalakturonase pada klarifikasi sari buah naga super merah dalam pembuatan sirup menunjukkan adanya pengaruh terhadap parameter viskositas dengan nilai berkisar antara $0,102 \pm 0,00 \mathrm{cP}$ hingga $0,137 \pm 0,01$ cP. Berdasarkan Tabel 5, hasil analisis two way anova menunjukkan tidak adanya pengaruh penggunaan enzim pektinesterase pada klarifikasi sari buah naga super merah dalam pembuatan sirup terhadap parameter nilai viskositas. Nilai viskositas dengan penambahan enzim pektinesterase berkisar antara $0,115 \pm 0,01 \mathrm{cP}$ hingga $0,125 \pm 0,01$ cP. Pada penambahan enzim poligalakturonase dan pektinesterase ternyata tidak terdapat interaksi yang nyata terhadap penurunan viskositas sirup buah naga super merah. Interaksi tersebut memiliki nilai korelasi yang lemah.

Dengan perlakuan enzim pektinase khususnya poligalakturonase, degradasi pektin mempengaruhi penurunan kemampuan mengikat air (WHC) dari pektin.
Air bebas dilepaskan ke dalam sistem yang mengakibatkan viskositas menurun (Singh et al., 2012). Perlakuan enzimatik untuk degradasi pektin dapat menyebabkan reduksi pada kemampuan untuk mempertahankan air, mengurangi viskositas sari buah dengan pembebasan air ke sistem (Sandri et al., 2011).

\section{Perlakuan Terbaik}

Berdasarkan hasil penelitian yang telah dilakukan yaitu kombinasi enzim poligalakturonase dan enzim pektinesterase pada klarifiaksi sari buah naga super merah dalam pembuatan sirup, maka dipilih perlakuan terbaik yaitu pada kombinasi konsentrasi enzim poligalakturonase dan enzim pektinesterase masing-masing $0,11 \%$ dan $0,5 \%$. Hasil ini dilihat dari perlakuan yang memberikan pengaruh terhadap interaksi antara kedua enzim serta untuk semua parameter.

Tabel 6 Penentuan Konsentrasi Terbaik

\begin{tabular}{|c|c|c|c|c|c|c|}
\hline \multirow{2}{*}{$\mathrm{No}$} & \multirow{2}{*}{ Sampel } & \multicolumn{5}{|c|}{ Sirup Buah } \\
\hline & & $\mathrm{pH}$ & TPT & $\% \mathrm{~T}$ & Viskositas & $\mathrm{Jml}$ \\
\hline 1 & Kontrol & $4,240^{\mathrm{a}}$ & $40,533^{\mathrm{T}}$ & $63,966^{\text {bc }}$ & $0,132^{\mathrm{b}}$ & 1 \\
\hline 2 & PG 0\%; PE 0,5\% & $4,243^{a}$ & $39,666^{\mathrm{e}}$ & $72,700^{\mathrm{e}}$ & $0,1^{2}{ }^{\text {ab }}$ & 3 \\
\hline 3 & PG 0\%; PE $1 \%$ & $4,236^{a}$ & $39,133^{\mathrm{d}}$ & $73,000^{\mathrm{e}}$ & $0,137^{\text {ab }}$ & 3 \\
\hline 4 & PG 0\%; PE 1,5\% & $4,253^{a}$ & $39,133^{\mathrm{d}}$ & $61,300^{\mathrm{ab}}$ & $0,164^{b}$ & 1 \\
\hline 5 & PG $0,09 \% ;$ PE $0 \%$ & $4,256^{a}$ & $39,266^{\mathrm{d}}$ & $73,700^{e}$ & $0, \mathbf{1 4 5}^{\text {ab }}$ & 3 \\
\hline 6 & PG $0,09 \% ;$ PE $0,5 \%$ & $4,256^{\mathrm{a}}$ & $39,000^{\mathrm{cd}}$ & $72,700^{\mathrm{e}}$ & $0,129^{a b}$ & 3 \\
\hline 7 & PG $0,09 \% ;$ PE $1 \%$ & $4,243^{a}$ & $39,133^{d}$ & $73,5^{3} 3^{\mathrm{e}}$ & $0, \mathbf{1 2 0}^{\text {ab }}$ & 3 \\
\hline 8 & PG $0,09 \% ;$ PE $1,5 \%$ & $4,276^{a}$ & $39,266^{\mathrm{d}}$ & $60,800^{\mathrm{a}}$ & $0,105^{\mathrm{a}}$ & 2 \\
\hline 9 & PG $0,1 \% ;$ PE $0 \%$ & $4,260^{a}$ & $39,200^{\mathrm{d}}$ & $69,100^{\mathrm{d}}$ & $0,115^{a b}$ & 2 \\
\hline 10 & PG $0,1 \%$; PE $0,5 \%$ & $4,256^{a}$ & $39,200^{\mathrm{d}}$ & $62,266^{\mathrm{ab}}$ & $0,100^{\mathrm{a}}$ & 2 \\
\hline 11 & PG $0,1 \% ;$ PE $1 \%$ & $4,266^{a}$ & $38,733^{\mathrm{c}}$ & $66,733^{\mathrm{cd}}$ & $0,108^{\mathrm{a}}$ & 2 \\
\hline 12 & PG $0,1 \% ;$ PE $1,5 \%$ & $4,260^{a}$ & $39,200^{\mathrm{d}}$ & $72,500^{\mathrm{e}}$ & $0,109^{\mathrm{a}}$ & 3 \\
\hline 13 & PG $0,11 \% ;$ PE $0 \%$ & $4,263^{\mathrm{a}}$ & $38,200^{\text {ab }}$ & $68,733^{\mathrm{d}}$ & $0,1_{120}{ }^{\text {ab }}$ & 3 \\
\hline 14 & PG $0,11 \% ;$ PE $0,5 \%$ & $4,303^{\mathrm{a}}$ & $38,133^{\mathrm{ab}}$ & $74,500^{\mathrm{e}}$ & $0,128^{\text {ab }}$ & 4 \\
\hline 15 & PG $0,11 \% ;$ PE $1 \%$ & $4,303^{a}$ & $38,200^{\text {ab }}$ & $72,133^{\mathrm{e}}$ & $0,115^{\text {ab }}$ & 4 \\
\hline 16 & PG $0,11 \% ;$ PE $1,5 \%$ & $4,313^{\mathrm{a}}$ & $38,000^{a}$ & $65,133^{\mathrm{c}}$ & $0,110^{\mathrm{a}}$ & 3 \\
\hline
\end{tabular}

\section{KESIMPULAN}

Berdasarkan hasil penelitian dan pembahasan maka dapat diambil kesimpulan bahwa penggunaan variasi konsentrasi enzim poligalakturonase bakteri Bacillus licherniformis strain GD2a AR2 dan enzim pektineterase bakteri Bacillus licherniformis strain GD2a KK2 berpengaruh terhadap parameter nilai total padatan terlarut dan nilai transmitansi. Sedangkan kombinasi kedua enzim tidak berpengaruh terhadap nilai $\mathrm{pH}$ dan viskositas. Konsentrasi terbaik hasil klarifikasi sari buah naga super merah dalam pembuatan sirup terdapat pada sampel dengan penambahan $0,11 \%$ enzim poligalakturonase bakteri Bacillus licherniformis strain GD2a AR2 dan 0,5\% 
enzim pektinesterase bakteri Bacillus licherniformis strain GD2a KK2.

\section{DAFTAR PUSTAKA}

Anggraini, D.P., Anna R, Sasangka P, Diah M. (2013). Pengaruh Ion-ion Logam tehadap Aktivitas Pektinase dari Aspergillus niger pada Penjernihan Sari Buah Jambu. NATURAL B, Vol. 2 No. 1: 1 .

Badan Standarisasi Nasional. (2013). SNI 3544:2013. Sirup. Jakarta.

Beg, Q.K., Kapoor M, Mahajan L., Hoondal G.S. (2001). Microbial Xylanases and Their Industrial Applications: A Review. J. Appl. Microbial. Biotechnol, Vol. 56 No. 3-4: 326-338.

Farikha, I. N , Choirul A, Esti W. (2013). Pengaruh Jenis dan Konsentrasi Bahan Penstabil Alami Terhadap Karakteristik Fisikokimia Sari Buah Naga Merah (Hylocereus polyrhizus) Selama Penyimpanan. Jurnal Teknosains Pangan, Vol. 2 No. 1: 30-37.

Hariyati, N. M. (2006). Ekstraksi dan Karakterisasi Pektin Dari Limbah Proses Pengolahan Jeruk Pontianak (Citrus Nobilis Var Microcarpa). Bogor. Institut Pertanian Bogor. Skripsi.

Jaafar, R.A., Rahman, A. R. B. A.; Mahmod, N. Z. C, Vasudevan, R. (2009). Proximate Analysis of Dragon Fruit (Hylocereus polyrhizus). American Journal of Applied Science Vol. 6 No.7:1341-1346.

Kertez, Z.I. (1995). Pectic Enzyme: Methods in Enzymology. Vol 1: 158-162. Academic Press: New York.

Kohn, R, Kovac P. (1978). Dissociation Constants of D-galacturonic Acid and D-glucuronic Acid and their O-methyl Derivates. Chem. Zvesti Vol. 32 No. 4: 34.

Kristanto, D. (2008). Buah Naga : Pembudidayaan di Pot dan di Kebun. Penebar Swadaya: Jakarta.
Kulvanen, J, Dominik M, Yanming W, Satu H, Merja P, Peter R, Marilyn G. W. (2012). Engineering Filamentous Fungi for Conversion of D-Galacturonic Acid to L-Galactonic Acid. Applied and Enviromental Microbiology, Vol. 78 No. 24: 59.

Nurdjanah, N. (2003). Penjernihan Sirup Pala Dengan Chitosan dan Hemisellulase. Jurnal Teknologi Industri Pertanian, Vol. 16 No. 1: 3.

Ordonez, R.G, Morlon, J; Gasparian, S, Guyot, J.P. (1998). Occurence of A Thermoachidophilic Cell-bound Exopectinase in Alicyclobacillus acidocaldarius. Folia Microbiology, Vol. 4 No. 6: 126.

Ortega, N, S.de Diego, M. Perez-Mateos, M.D. Busto. (2004). Kinetic Properties and Thermal Behaviour of Polygalacturonase Used in Fruit Juice Clarification. Food Chemistry, Vol. 88: 48-50.

Pedrolli, D.B, Monteiro, A. C, Gomes, E, Carmona, E. C. (2009). Pectin and Pectinases: Production, Characterization and Industrial Application of Microbial Pectinolytic Enzymes. The Open Biotechnology Journal, Vol. 3 No. 9: 918.

Sandri, I. G. (2011). Clarification of Fruit Juice by Fungal Pectinases. LWT-Food Science and Technology Vol. 44: 2219.

Sharma, H. P, Hiral P, Sugandha S. (2014). Enzymatic Extraction and Clarification of Juice from Various Fruits-A Review. Trends in Post Harvest Technology Vol. 2 No. 1: 2.

Singh, A, Sanjay K, H.K. Sharma. (2012). Effect of Enzymatic Hydrolysis on the Juice Yield from Bael Fruit (Aegle maemelos Correa) Pulp. American Journal of Food Technology, Vol. 7 No. 9: 64.

Smith, B. (1968). Properties of Pectin Fraction Separated on Diethylleaminoethyl-Cellulose Columns. AVI Publ. Inc., Westport, Connecticut. 
Widowati,E., Utami, R dan Khalistyatika, K. (2017). Screening and Characterization pf Polygalacturonase as Potential Enzyme for keprok Garut orange (Citrus nobilis var chrysocarpa) Juice Clarification. Journal of Physics: Conference of Series 909 (1), 012088. 